\title{
Diversity of shifting cultivation cycles among small-scale farmers in Peruvian Amazon
}

\author{
Bohdan Lojka $^{1^{\star}}$, Jan Banout $^{1}$, Lucie Banoutova ${ }^{1}$, Vladimir Verner ${ }^{1}$, Patrick Van Damme ${ }^{2}$ \\ ${ }^{1}$ Institute of Tropics and Subtropics, Czech University of Life Sciences, Prague, Czech Republic; \\ ${ }^{2}$ Laboratory of Tropical and Subtropical Agriculture and Ethnobotany, Ghent University, Ghent, Belgium; \\ ${ }^{*}$ Corresponding Author: 1ojka@,its.czu.cz
}

Received 25 November 2010; revised 16 February 2011; accepted 15 March 2011.

\section{ABSTRACT}

Although shifting cultivation is practiced by millions of farmers, it is often blamed for causing deforestation and keeping farmers in poverty. Our study focused on the Amazon basin, where small-scale farmers widely practice shifting cultivation. The objective was to identify the diversity in land use after initial slash-and-burn land clearing among migrant peasants. Our research aimed at documenting typical crop sequences, plant species composition and specific lengths of particular phases of shifting cultivation cycles on the basis of farmers related field histories. Land use was examined in two settlements: Antonio Raimondi and Pimental in Ucayali region, Peru. Data was gathered via semi-structured questionnaires that focused on the sociodemographic characterization of agriculture-dependent households and their land use characteristics. More in-depth assessments of crop occurrence, cropping sequence and length of the different shifting cultivation cycles were conducted on 114 fields in Pimental and 44 fields in Antonio Raimondi. Interview analysis showed that in both villages, forest cover has substantially decreased over the last 10 years. Results also indicate considerable variation in swidden-fallow systems. Whereas settlers in Antonio Raimondi plant annual crops after slashing and burning the forest, settlers in Pimental gave more importance to perennial crops. Progress in deforestation and land degradation is relatively more pronounced in the younger settlement (Antonio Raimondi). These differences are likely caused by the different social backgrounds of settlers and histories of each site. Small-scale farmers in the study area are now facing a problem with the transition from shift- ing cultivation to sedentary farming. Farmers in areas with a prevalence of annual cropping use a significantly shorter fallow period, which causes a higher rate of forest degradation. As annual cropping seems to be unsustainable in relation with forest degradation, farmers should either use a longer natural fallow to sustain longer cropping cycles, or shift to tree-based land use systems.

Keywords: Agroforestry; Deforestation; Land Degradation; Slash-And-Burn; Swidden-Fallow

\section{INTRODUCTION}

Despite rapid economic development in many tropical countries, shifting cultivation is practiced by millions of farmers and has been blamed for causing deforestation and keeping farmers in poverty [1]. Exact figures about the total area under shifting cultivation are not available, but it is still applied in at least some 40 - 50 countries [2]; and shifting cultivation constitutes an important part of the 850 million hectares of secondary forest management in tropical Africa, America and Asia [3]. Some researchers have claimed that shifting cultivation is practiced on as much as $30 \%$ of the world's exploitable soils [4]. Figures for the number of people depending on this system are also uncertain and range between 40 to 500 million [4-7].

Slash-and-burn agriculture can only be sustainable when population densities are low enough to allow reestablishment of the forest within slash-and-burn fields. However, under the pressure of increasing populations, fallow periods are drastically reduced and the system degrades, resulting in serious soil erosion and a decline in soil fertility and productivity [8]. This assumption is commonly accepted, however, empirical evidence is scarce. Mertz et al. [1] have demonstrated that fallow length is a weak predictor of crop yields and that other 
factors such as fertilizer inputs, drought, flooding or pests and diseases are more important determinants of yield. Thus, fallow length is not the best proxy for assessing sustainability of the system.

Shifting cultivation is thought to account for about one third of deforestation in the Amazon, while cattle ranching is responsible for at least half of the forest retreat [9]. After the annual crop stage of the slash-andburn cycle, farmers leave the land for short fallow, or convert is to other uses, including pastures for cattle and perennial crops [10].

Although a relatively large amount of literature has been generated on the subject, a number of aspects of the system is still poorly understood [1]. More applied research to explain local complexities of the system and to demonstrate to what extent shifting cultivation contributes to local livelihoods and environmental (mis)management is still needed.

Our study focused on the slash-and-burn system in the Ucayali region of the Peruvian Amazon. Between 1999 and 2005, disturbance and deforestation rates throughout the Peruvian Amazon averaged 632 and $645 \mathrm{~km}^{2} \cdot \mathrm{yr}^{-1}$, respectively, whereby $64 \%$ of all damage was concentrated in the area around the Ucayali logging centre of Pucallpa and along the road network emanating from it [11]. In this region, colonists or migrating landless peasants lacking the traditional knowledge required for maintaining sustainability of their shifting cultivation system predominate. Generally, crop yields are decreasing and soil degradation is rapidly increasing. On such degraded land extensive grasslands have developed, dominated by Imperata spp. The latter is considered to be one of the world's worst weeds and a reliable indicator of land degradation $[12,13]$. These grasslands are mostly formed following annual bushfires that hinder the regeneration of woody vegetation [14]. Such landscape is considered as the final stage in the process of land degradation with an irreversible loss of forest cover and a permanent loss of agricultural income [15].

Our objective was to identify the diversity in land use after initial slash-and-burn among migrant peasants and to identify traditional technologies used in the cropping cycles (from original forest, through cropping sequence to secondary fallow), in order to understand the factors influencing the changes in local agricultural systems. Our research aimed at documenting and characterising typical crop sequences, plant species composition and lengths of particular phases of shifting cultivation cycles on the basis of collecting data about field history. Through this documentation, we can quantify how local households change original natural environment on their farming land. One of the most striking features of land use practices in tropical environments is their great di- versity (use of plant species, varieties, cropping sequences). Therefore, by examining local differences, such research could provide valuable information about the varied economic opportunities, constraints on production, and land use decisions perceived by local farmers [16]. On the basis of these findings, new alternative land use methods can be proposed in order to improve sustainability of their farming.

\section{METHODS}

\subsection{Site Description}

Pucallpa, the capital of Ucayali region, is situated on the Ucayali River, $860 \mathrm{~km}$ from Lima, the capital of Peru, at $154 \mathrm{~m}$ above sea level, $8^{\circ} 23^{\prime} \mathrm{S}$ and $74^{\circ} 31^{\prime} \mathrm{W}$. Ucayali region borders Brazil to the east. Annual rainfall ranges 1500 - $3000 \mathrm{~mm}$ (with rainfall increasing in a western direction) with a mean annual precipitation of approximately $1600 \mathrm{~mm}$ around Pucallpa. Intense precipitation prevails during the wet months from February to May and from September to November [17]. Average annual temperature is around $25^{\circ} \mathrm{C}$, with a maximum of $31^{\circ} \mathrm{C}$ and a minimum of $19.5^{\circ} \mathrm{C}$. Soils include more favourable alluvial, seasonally-flooded riverine system entisols, where $\mathrm{pH}$ is about 7.7, available $\mathrm{P}$ is $15 \mathrm{ppm}$ and upland, well-drained ultisols of forested areas with an acid $\mathrm{pH}$ around 4.4 and low in $\mathrm{P}$ (around $2 \mathrm{ppm}$ ) [17]. In general, these soils have low quality for agriculture [18]. The upland terrain is usually flat or undulating. The original, natural vegetation is a tropical semi-evergreen seasonal forest, now mixed with palm forest, dominated by Mauritia spp. palms. Settlement around Pucallpa started in the 1940s after construction of the road linking the cities of Pucallpa and Lima, and was promoted by road improvements in the late 1960s.

For our study, two representative settlements (Antonio Raimondi and Pimental), located near the city of Pucallpa, were chosen. Both villages are situated in the Campo Verde district, which came into existence in 1982, and are connected with the Lima-Pucallpa highway. Antonio Raimondi is located $25 \mathrm{~km}$ west of Pucallpa. According to the head of the local municipality, this community was established in 1990 and, in 2005, there were 27 households (about 200 inhabitants). Due to slash-andburn farming, most of the forest has already been cut down and vast areas around the village are degraded and covered by Imperata grass. Farmers establish their fields either on already degraded plots, or else they go further to clear the primary or secondary forest and open a new field. Secondary forest (so-called purma) is a previously cultivated area that was left under fallow for 25 - 40 years. The most important crop is cassava (Manihot esculenta), which is considered the only crop which can be 
economically grown on degraded land infested by Imperata. Cassava mainly serves for household subsistence, but is often sold on the local market in Pucallpa as well. Other staple crops are rice (Oryza sativa), maize (Zea mays), bananas, plantains (Musa spp.) and cowpea (Vigna ungiculata), mainly grown on fields with better soil fertility, and usually planted after slashing and burning the secondary forest. In addition, nearly each household is surrounded by a homegarden with many fruit and timber trees mixed with vegetable and medicinal plants. Local households also depend on collecting non-timber forest products (medicinal plants, honey and fruit) from adjacent forests, whereas they also fish and hunt. All these products are sold on the local market in Pucallpa, which can be reached within one hour by local transport. However, this transport is expensive. Farmers usually own a few heads of cattle (on average 2 - 3 heads), sometimes pigs and horses, and most only raise poultry. They have very limited opportunity for any off-farm employment.

The second village, Pimental, located $35 \mathrm{~km}$ west of Pucallpa, is not very different from the previous site, but the community is older (established in 1972) and more prosperous, as farmers are more focused on cash crop growing. This community was established when the highway linking Lima with Pucallpa was improved in the 1970s. There were 56 households (about 400 inhabitants) in 2005. Large areas are covered by weedy grassland species such as Imperata spp. and Brachiaria spp. The land use system is based on the same methods of slashand-burn farming, although cultivation of the more economically-viable pepper (Piper nigrum) has a tradition in this zone. Farmers also grow (semi-) perennial crops such as pineapple (Ananas comosus), native fruit tree species and various citruses (Citrus spp.). Furthermore, settlers also have more opportunities for off-farm income generation.

\subsection{Data Collection and Evaluation}

Our methodology of data collection and evaluation was based on the similar study of Coomes and Burt [16] made in traditional community near Iquitos, Peru. In the period from June to October 2005, a survey was conducted in both above-mentioned villages. Data on general household characteristics were collected via semistructured interviews with local farmers. In each village, a sample of households practicing agriculture as their main activity was randomly chosen. Altogether, 27 households were interviewed: 11 in Antonio Raimondi (40\% of total number of households) and 16 in Pimental $(29 \%)$. The questionnaire was usually filled in by the household head, typically a male. The household interview focussed on demographic characteristics (e.g. size and composition through time), methods of shifting cul- tivation used, history of their agricultural practice, basic socio-economic data and additional information related to main crops and trees grown, land tenure and problems with agriculture. In addition, each respondent was accompanied to each of his/her fields where we assessed vegetation type, field size, crop composition and previous use. Each visit started with an initial delineation of the whole farm area. Then the area was divided into smaller parts according to current vegetation type and crop composition. The history of each field was reconstructed by asking the respondent to recall type and duration of each crop and forest fallow, beginning with present field cover and working backward through time. A total of 163 and 94 fields were thus inventoried Pimental and Antonio Raimondi, respectively. Generally, farmers were able to recall most of their experiences over the time they had lived in their particular location, though occasionally with some difficulty. By knowing crop/fallow durations in the sequence back through time, we were able to reconstruct, using manual spreadsheet, the history of each field held by the respective farmer. Based on this, data we were able to calculate various current and past land-use system sizes, their proportion of total farming land, and assess the changes in time. The data served for identification of several shifting cultivation cycles and determination of the most frequently planted crop and tree species. We used the independent two-sample t-test to reveal the statistically significant differences between both settlements. Household and field surveys afford a comprehensive and systematic analysis of variation and diversity in local shifting cultivation systems.

\section{RESULTS}

\subsection{General Household and Farm Characteristics}

Respondents have been living, on average, for 13 and 18 years in Antonio Raimondi and Pimental, respectively. In Pimental, $56 \%$ of respondents were born (or had lived) there since the community was established. Each household consists of, on average, four to five members (Table 1). On average, three household members work on a farm as their main activity (child labour was not counted but occurs). Average farm size is about 20 ha. We tried to assess farm size changes over the last 10 years. Only respondents living in their village since before 1995 were included in this attribute, 8 households from Antonio Raimondi and 9 from Pimental. For simplification, this group of respondents will be further referred to as "old residents". In both villages, farm size has slightly decreased over the last 10 years. There is an increasing trend in acquiring land tenure rights over this period. 
Table 1. Household demography and land availability in Antonio Raimondi and Pimental.

\begin{tabular}{|c|c|c|c|c|c|c|}
\hline & \multirow[t]{2}{*}{ Unit } & \multicolumn{2}{|c|}{ Pimental } & \multicolumn{2}{|c|}{ Antonio Raimondi } & \multirow{2}{*}{$\frac{\text { T-test }(0.05)}{\mathrm{p}}$} \\
\hline & & Mean & $\mathrm{SD}$ & Mean & SD & \\
\hline Total members of household* & pers. & 4.81 & \pm 1.91 & 4.09 & \pm 1.22 & 0.279 \\
\hline Age of household head* & year & 43.2 & \pm 13.7 & 49.4 & \pm 15.9 & 0.291 \\
\hline Farm size actual* & ha & 18.5 & \pm 11.0 & 20.7 & \pm 13.4 & 0.645 \\
\hline Farm size per family member* & ha & 4.7 & \pm 4.10 & 5.4 & \pm 3.81 & 0.645 \\
\hline Farm size 10 years ago** & ha & 21.4 & \pm 8.55 & 24.1 & \pm 12.5 & 0.243 \\
\hline$\%$ of fields with land tenure actual* & $\%$ & 84.8 & & 75.6 & & \\
\hline $\begin{array}{l}\% \text { of fields with land tenure } 10 \text { years } \\
\text { ago** }\end{array}$ & $\%$ & 82.0 & & 46.1 & & \\
\hline
\end{tabular}

Currently, more than $84 \%$ of the total area in Pimental and $75 \%$ in Antonio Raimondi is protected by land tenure rights. Especially in Antonio Raimondi, private land ownership has increased significantly over the last 10 years, although almost one fifth of all respondents in Pimental and one third in Antonio Raimondi does not have any land tenure rights at all.

\subsection{Land use Classification and Changes}

Based on farmers' responses, we identified nine different land use system, based on current plant species composition and use (Table 2). According to this classification, we assessed changes in land use within both villages over the last 10 years (Table 3). In 1995, a total of $64 \%$ of the farm land in Pimental was forested (residual forest or fallow) or covered by tree-dominated land use systems (tree crop plantation, agroforestry and homegardens); $36 \%$ was covered by pastures and only small parts were cropped by non-wood crops $(3 \%)$, or were degraded (2\%). In Antonio Raimondi, $73 \%$ of the farmed land was forested or covered by tree-dominated land use systems in 1995; pastures and degraded land covered $13 \%$ and $11 \%$, respectively; only $3 \%$ was cropped by non-wood crops. Differences between villages could be explained by the fact settlements in Pimental are older and so that farmers had already deforested higher proportion of their land.

After 10 years, there has been an important decrease in forested land in both villages. In Pimental, reduction in forested area amounted to $23 \%$ whereas in Antonio Raimondi it reached as much as $47 \%$. Currently, forests and fallows cover only $21 \%$ and $11 \%$ of farm land in Pimental and Antonio Raimondi, respectively. In both villages, we see the same trend of land use transition: decrease in forest cover and increase in grass cover, evidenced by higher proportion of pasture and degraded land (44\% increase in Antonio Raimondi). Generally, land classified as pasture is used extensively having very low stocking rate. During this period, there have been only slight changes in proportion of farming area occupied by young fallow, homegardens, tree plantation, agroforestry systems and non-wood crops. It seems that households did not increase their total cropped extension substantially over the last 10 years.

\subsection{Field Characteristics and Swidden-Fallow Cycles}

A total of 163 and 94 fields were studied for assessment of current land use and specific shifting cycles in Pimental and Antonio Raimondi, respectively (Table 4). Each household in the sample possesses a collection of plots in different phases, which, together, represent its swidden-fallow agroforestry portfolio. On average, households in Pimental hold a total of 10 plots (7 in crops, 1 in forest or fallow and 2 under pasture or degraded land). About $27 \%$ of household land holding is currently used for annual or perennial cropping, $20 \%$ is forested or under fallow, whereas the remaining $53 \%$ is pasture or degraded land. Households in Antonio Raimondi hold, on average, a total of 8 plots ( 5 in crops, 1 in forest or fallow and 2 under pasture or degraded land). Nearly $20 \%$ of household land holdings is used for cropping, $11 \%$ is under forest or fallow; the remaining $69 \%$ is pasture and degraded land. It is evident that land in Antonio Raimondi is currently more deforested and degraded than in Pimental.

Altogether, 87 complete swidden-fallow cycles were documented from the field histories in Pimental: 62 fields were claimed from residual forest, 16 originated from old fallow, 4 from young fallow, whereas the remaining 5 fields were established from pasture. We identified seven principal cropping cycles established after slashing and burning of residual forest (Figure 1) and four most frequent crops; i.e. rice, cassava, banana and pepper. After clearance, the deforested land was used for planting various crops. Rice and pepper interplanted with bananas were first planted on $51 \%$ and $41 \%$ of all fields, respectively. On the remaining $8 \%$ of fields, 
Table 2. Classification of land use systems.

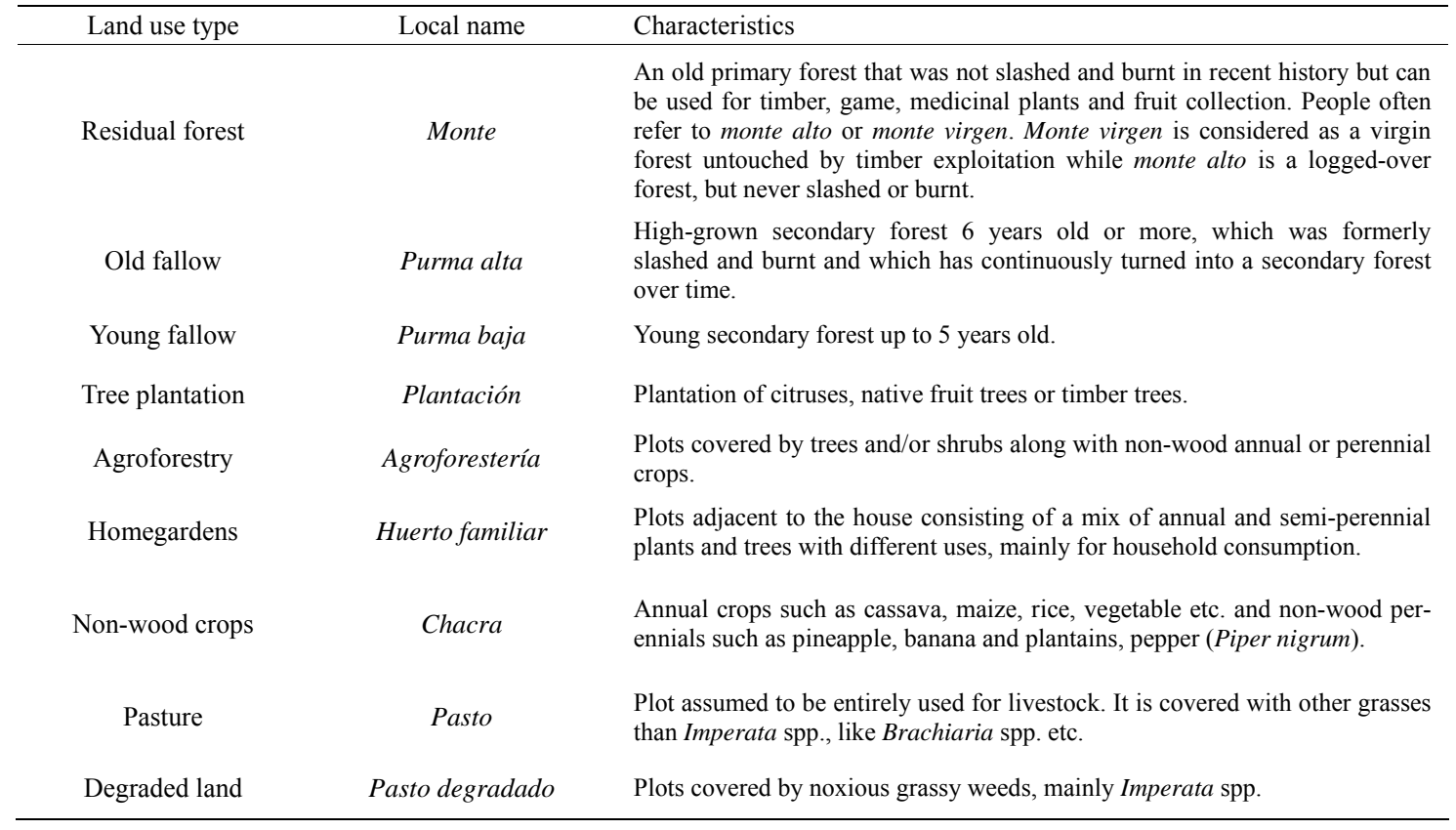

Table 3. Land use (\% area) and total area of specific land use type in 1995 and 2005.

\begin{tabular}{|c|c|c|c|c|c|c|c|c|c|c|}
\hline & \multicolumn{5}{|c|}{ Pimental } & \multicolumn{5}{|c|}{ Antonio Raimondi } \\
\hline & \multicolumn{2}{|c|}{$1995 * *$} & \multicolumn{2}{|c|}{$2005 *$} & \multirow{2}{*}{$\begin{array}{c}\text { Difference } \\
{[\%]}\end{array}$} & \multicolumn{2}{|c|}{$1995 * *$} & \multicolumn{2}{|c|}{$2005^{*}$} & \multirow{2}{*}{$\begin{array}{c}\text { Difference } \\
{[\%]}\end{array}$} \\
\hline & [ha] & {$[\%]$} & [ha] & {$[\%]$} & & [ha] & {$[\%]$} & [ha] & {$[\%]$} & \\
\hline Residual forest & 29.8 & 14 & 22.5 & 8 & -6 & 47.0 & 27 & 12.0 & 5 & -22 \\
\hline Old fallow & 59.5 & 28 & 34.5 & 12 & -16 & 49.8 & 29 & 7.0 & 3 & -26 \\
\hline Tree plantation & 26.5 & 12 & 36.6 & 12 & 0 & 12.8 & 7 & 10.5 & 5 & -2 \\
\hline Agroforestry & 10.2 & 5 & 20.4 & 7 & 2 & 10.0 & 6 & 14.3 & 6 & 0 \\
\hline Homegarden & 5.8 & 3 & 6.9 & 2 & -1 & 3.0 & 2 & 6.0 & 3 & 1 \\
\hline Non-wood crops & 6.5 & 3 & 14.4 & 5 & 2 & 4.85 & 3 & 15.4 & 7 & 4 \\
\hline Pasture & 68.3 & 32 & 140.0 & 47 & 15 & 23.6 & 13 & 76.0 & 33 & 20 \\
\hline Degraded land & 4.0 & 2 & 17.5 & 6 & 4 & 18.8 & 11 & 80.9 & 35 & 24 \\
\hline
\end{tabular}

*Values for all sampled respondents in Pimental $(\mathrm{n}=16)$ and Antonio Raimondi $(\mathrm{n}=11)$.** Values only for sampled older respondents living in Pimental $(\mathrm{n}=11)$ and Antonio Raimondi $(\mathrm{n}=8)$ since before 1995.

Table 4. Field size by land use type in 2005 .

\begin{tabular}{|c|c|c|c|c|c|c|c|c|c|c|c|}
\hline & \multicolumn{5}{|c|}{ Pimental } & \multicolumn{5}{|c|}{ Antonio Raimondi } & \multirow{2}{*}{$\begin{array}{c}\text { T-test } \\
(0.05) \\
p\end{array}$} \\
\hline & $\begin{array}{l}\text { No. of } \\
\text { plots }\end{array}$ & $\begin{array}{l}\text { Total } \\
\text { (ha) }\end{array}$ & $\begin{array}{l}\text { Mean } \\
\text { (ha) }\end{array}$ & $\begin{array}{l}\text { SD } \\
\text { (ha) }\end{array}$ & Range (ha) & $\begin{array}{l}\text { No. of } \\
\text { plots }\end{array}$ & $\begin{array}{l}\text { Total } \\
\text { (ha) }\end{array}$ & $\begin{array}{c}\text { Mean } \\
\text { (ha) }\end{array}$ & $\begin{array}{l}\text { SD } \\
\text { (ha) }\end{array}$ & $\begin{array}{c}\text { Range } \\
\text { (ha) }\end{array}$ & \\
\hline Residual forest & 4 & 22.5 & 5.63 & \pm 6.61 & $0.5-15.0$ & 4 & 12.0 & 3.00 & \pm 4.06 & $0.5-9.0$ & 0.524 \\
\hline Old fallow & 10 & 34.5 & 3.45 & \pm 2.70 & $1.0-9.5$ & 5 & 7.0 & 1.40 & \pm 0.82 & $0.5-2.5$ & 0.127 \\
\hline Young fallow & 4 & 3.6 & 0.89 & \pm 0.83 & $0.06-2.0$ & 3 & 6.0 & 2.00 & \pm 1.73 & $1.0-4.0$ & 0.305 \\
\hline Tree plantation & 46 & 36.6 & 0.79 & \pm 0.72 & $0.1-4.5$ & 10 & 10.5 & 1.05 & \pm 0.95 & $0.25-3.3$ & 0.334 \\
\hline Agroforestry & 31 & 21.7 & 0.70 & \pm 0.67 & $0.18-3.0$ & 14 & 14.3 & 1.02 & \pm 0.65 & $0.25-2.0$ & 0.146 \\
\hline Homegarden & 14 & 6.9 & 0.49 & \pm 0.33 & $0.1-1.0$ & 9 & 6.0 & 0.67 & \pm 0.25 & $0.5-1.0$ & 0.190 \\
\hline Non-wood crops & 26 & 13.6 & 0.52 & \pm 0.51 & $0.02-2.0$ & 23 & 14.4 & 0.63 & \pm 0.79 & $0.1-4.0$ & 0.585 \\
\hline Pasture & 22 & 141.0 & 6.40 & \pm 6.81 & $0.5-25.0$ & 12 & 75.9 & 6.33 & \pm 4.48 & $0.7-13.0$ & 0.975 \\
\hline Degraded land & 6 & 17.5 & 2.92 & \pm 2.01 & $0.5-5.0$ & 14 & 80.9 & 5.78 & \pm 5.96 & $0.1-17.0$ & 0.272 \\
\hline Total & 163 & 298.0 & & & & 94 & 227.0 & & & & \\
\hline
\end{tabular}




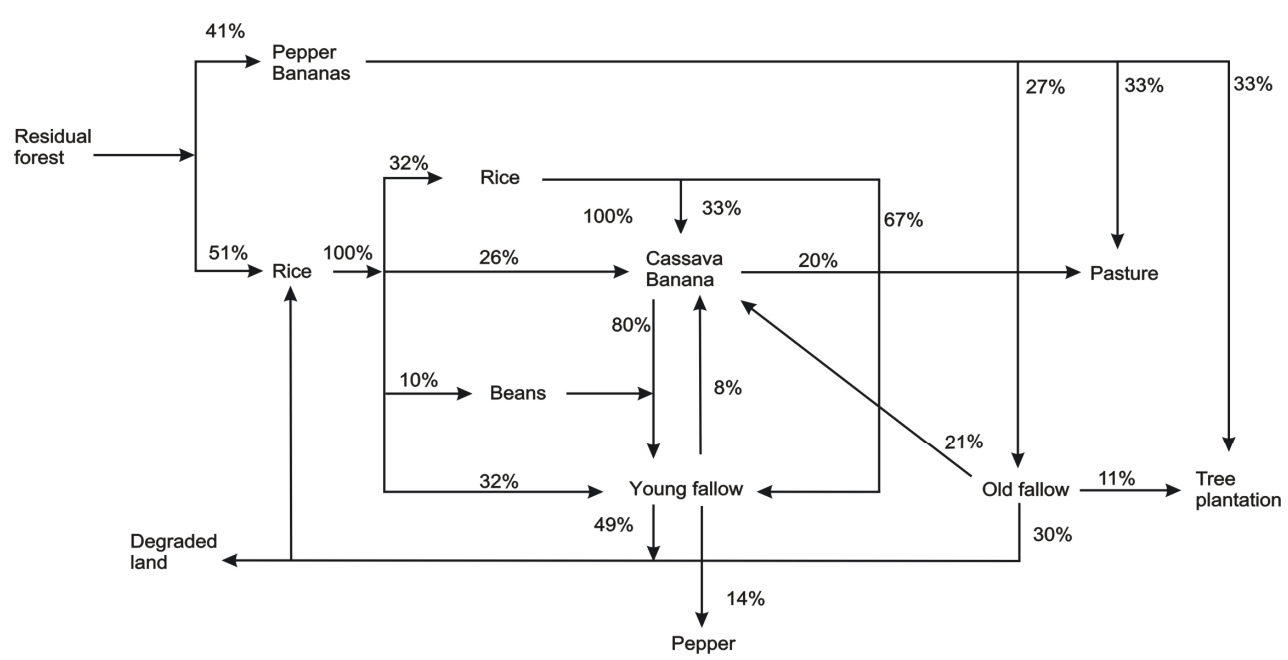

Figure 1. Typical swidden-fallow cycles on fields in Pimental village after clearing of the forest (No. of fields 87 , no. of cycles 7 , no. of crops 4 , mean cycle length 12 years, mean fallow length 6 years).

other crops such as maize, pineapple, sugar cane or vegetables were planted. After harvesting rice subsequent crops planted were typically cassava, banana/ plantain, cowpeas or again rice. The second most common cycle started by an initial crop mixture of pepper with bananas. Pepper is grown for 8 years on average; at the end of this cycle, the field is usually left to pasture, tree plantation, or fallow. In general, one cycle length varied from 1.5 to 27 years, with a mean duration of 6 years of fallow and a mean total cycle length of 12 years. The shortest cycle was "rice-short fallow-rice" with a minimum of 18 months and a mean duration of 2.7 years.

In Antonio Raimondi, 48 complete swidden-fallow cycles were identified from the field histories: 28 fields were established from forest, 9 originated from old fallow, 8 from degraded land whereas 2 fields were established from pasture. We identified eight principal cropping cycles established after slashing and burning of residual forest (Figure 2) and five most frequent crops; i.e. rice, cassava, banana, maize and cowpea. Rice and cassava/banana were planted on $56 \%$ and $31 \%$ of all fields originating from forest, respectively. Rice $(56 \%)$, cassava/bananas (31\%) and maize/cowpeas (12\%) were the first crops to be grown after forest clearance. After rice, crop mixtures that followed were typically cassava/banana (33\%) and maize/cowpea (11\%); $45 \%$ of the land was left fallow; and pasture was established in $11 \%$ of the cases. In addition to rice, cassava/bananas were also grown as the first crops after forest clearing. Very often, farmers repeat planting of a cassava/banana mixture subsequently for several years. Cycle length varied from 17 months to 10 years, with a mean duration of 3 years of fallow and a mean total cycle length of 5 years. The shortest cycle was "rice - short fallow - rice", with a minimum duration of 17 months. In both villages, the final land use system in the cycle is either tree-based (fallow, tree plantation or agroforestry) or, as in the majority of cases, the soil is so severely depleted and is left as a low-grade pasture or degraded land without any economic use.

\subsection{Crop and Tree Species Diversity}

A total of 100 tree and crop species (90 in Pimental and 55 in Antonio Raimondi) were found on 158 fields (114 in Pimental and 44 in Antonio Raimondi). The largest variety of species was encountered in tree plantations (70 and 37 species in Pimental and Antonio Raimondi, respectively). Plots with non-wood crops were generally the least diverse (13 and 16 species in Pimental and Antonio Raimondi, respectively). Despite the rich overall diversity of crops observed across fields, most individual plots contained relatively high densities of a small number of crops. As farmers mentioned, banana, cassava, pineapple and rice are the most widely planted crop species, whereas citruses, guaba (Inga edulis) and peach palm (Bactris gasipaes) are the most widely planted tree species (Table 5).

\section{DISCUSSION}

In both villages, it was observed that, over the last 10 years, mean farm size decreased while percentage of land with secure tenure significantly increased. Shifting cultivation patterns are different in each settlement. In both villages, we found a large decrease in forest cover over the last 10 years. In 1995, residual forest covered $14 \%$ and $27 \%$ of farmers' fields in Pimental and Antonio Raimondi, respectively, while $30 \%$ and $31 \%$ of farm land, respectively, was kept fallow. Fujisaka and White [10], while conducting their study around Pucallpa in 


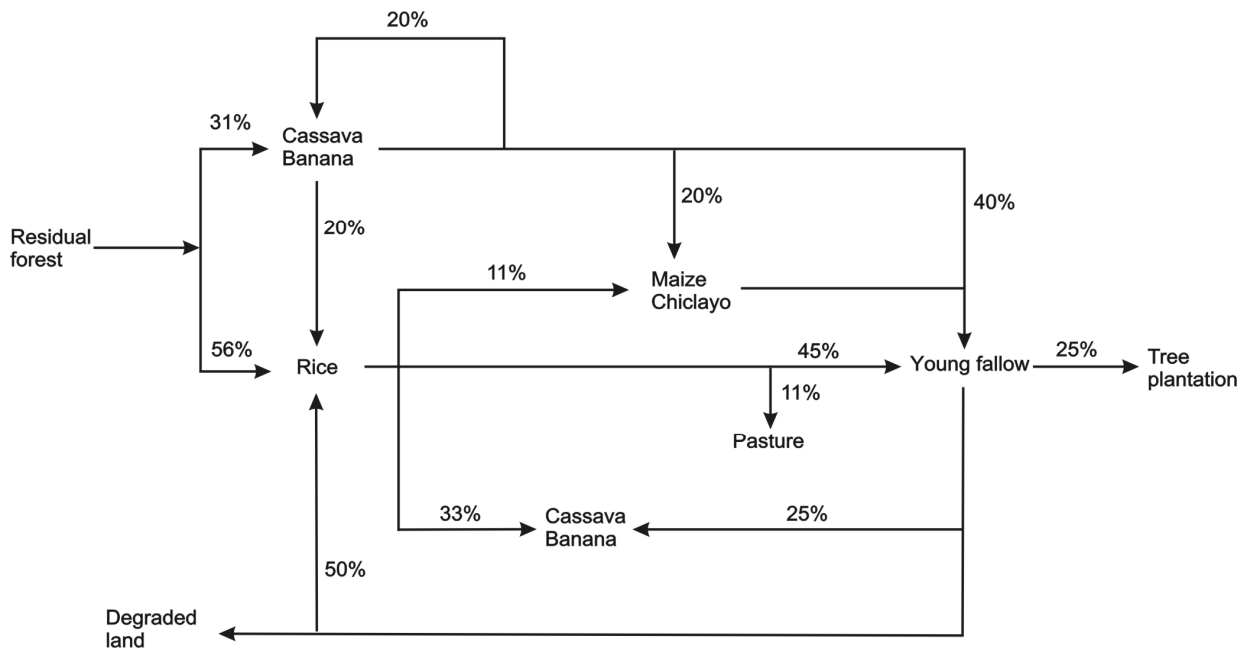

Figure 2. Typical swidden-fallow cycle on fields in Antonio Raimondi village after clearing of the forest. (No. of fields 48 , no. of cycles 8 , no. of crops 5 , mean cycle length 5 years, mean fallow length 3 years).

Table 5. Most frequently cultivated crop and tree species on fields in Pimental (PIM) and Antonio Raimondi (AR).

\begin{tabular}{|c|c|c|c|c|c|}
\hline \multirow[t]{3}{*}{ Vernacular name } & \multirow[t]{3}{*}{ Scientific name } & \multirow[t]{3}{*}{ Product } & \multicolumn{3}{|c|}{ Frequency of occurrence } \\
\hline & & & Total & PIM & $\mathrm{AR}$ \\
\hline & & & $(\mathrm{n}=158)$ & $(\mathrm{n}=114)$ & $(\mathrm{n}=44)$ \\
\hline \multicolumn{6}{|l|}{ Crop species } \\
\hline Banana & Musa spp. & Fruit & 42 & 26 & 16 \\
\hline Cassava & Manihot esculenta & Tuber & 40 & 22 & 18 \\
\hline Rice & Oryza sativa & Grain & 25 & 12 & 13 \\
\hline Pepper & Piper nigrum & Condiment & 21 & 21 & 0 \\
\hline Pineapple & Ananas comosus & Fruit & 20 & 12 & 8 \\
\hline Sugar cane & Saccharum officinarum & Juice/sugar & 15 & 8 & 7 \\
\hline Coca & Erythroxylum coca & Stimulant & 8 & 6 & 2 \\
\hline Cocona & Solanum sessiliflorum & Fruit & 8 & 0 & 8 \\
\hline Bijao & Calathea sp. & Vegetable & 7 & 7 & 0 \\
\hline Cowpea & Vigna ungiculata & Bean & 7 & 4 & 3 \\
\hline Maize & Zea mays & Grain & 7 & 4 & 3 \\
\hline \multicolumn{6}{|l|}{ Tree species } \\
\hline Citrus & Citrus spp. & Fruit & 88 & 75 & 13 \\
\hline Guaba & Inga edulis & Fruit & 38 & 23 & 15 \\
\hline Peach palm & Bactris gasipaes & Fruit & 33 & 27 & 6 \\
\hline Caimito & Pouteria caimito & Fruit & 22 & 12 & 10 \\
\hline Tahuari & Tabebuia sp. & Timber & 21 & 18 & 3 \\
\hline Sangre de grado & Croton lechleri & Latex & 20 & 18 & 2 \\
\hline Caoba & Swietenia macrophylla & Timber & 19 & 15 & 4 \\
\hline Cedro & Cedrela odorata & Timber & 19 & 15 & 4 \\
\hline Mango & Mangifera indica & Fruit & 19 & 8 & 11 \\
\hline Aguaje & Maurici flexuosa & Fruit & 15 & 11 & 4 \\
\hline Umari & Pouraqueiba sericea & Fruit & 13 & 11 & 2 \\
\hline Capirona & $\begin{array}{l}\text { Calicophyllum } \\
\text { spruceanum }\end{array}$ & Timber & 13 & 10 & 3 \\
\hline Ishpingo & Amburana clarensis & Timber & 13 & 10 & 3 \\
\hline Shebon & Scheelea bassleriana & Thatch & 12 & 10 & 2 \\
\hline
\end{tabular}




\begin{tabular}{|c|c|c|c|c|c|}
\hline Bolaina & Guzama crinita & Timber & 13 & 8 & 5 \\
\hline Carambola & Averrhoa carambola & Fruit & 11 & 8 & 3 \\
\hline Anona & Rollinia mucosa & Fruit & 9 & 5 & 4 \\
\hline Coconut & Cocos nucifera & Nut & 9 & 5 & 4 \\
\hline Camu-camu & Myrciaria dubia & Fruit & 8 & 7 & 1 \\
\hline Macambo & Theobroma bicolor & Fruit & 8 & 5 & 3 \\
\hline $\begin{array}{l}\text { Mamey (poma } \\
\text { rosa) }\end{array}$ & Syzygium sp. & Fruit & 8 & 7 & 1 \\
\hline Avocado & Persea americana & Fruit & 8 & 7 & 1 \\
\hline Shimbillo & Inga spp. & Fruit & 8 & 7 & 1 \\
\hline Guanabana & Anona muricata & Fruit & 7 & 5 & 2 \\
\hline
\end{tabular}

1996, found slightly higher numbers: $27 \%$ forest and $39 \%$ fallow. In 2005 , about $12 \%$ of the land was covered by forest, $13 \%$ by fallow and $53 \%$ by grass vegetation (pasture and degraded land) in Pimental, whereas only about 5\% was forest, 6\% fallow and about 68\% grass vegetation in Antonio Raimondi. Furthermore, in Pimental we find more tree plantations (either fruit or timber trees) than in Antonio Raimondi. This is probably due to the divergent histories of the sites. Pimental was established immediately after timber exploitation of the forest by logging companies, whereas Antonio Raimondi was established as a consequence of increasing population pressure in Pucallpa. It would seem that, in the older Pimental settlement, cultivation has acquired more permanent character and whereas land use systems are based on tree cultivation, especially of citruses.

Even though the ratio of land degradation and forest destruction in 1995 was higher in Pimental, further deforestation proceeded relatively slowly, as compared to what happened in Antonio Raimondi. This could probably be explained by a relatively better agricultural and socio-economic situation in Pimental. In the letter community, planting of pepper and fruit trees has a long tradition and this makes the village more prosperous. As a consequence, settlers prefer long-term plantation crops, while in Antonio Raimondi they prefer annual or short-term perennial crops.

We found that shifting cultivation cycles are very diverse in our study area from the points of view of cycle length, plot and crop composition. In both villages, basic cycle components are staple crops such as rice, cassava, banana, maize and cowpeas. In Pimental, farmers also grow pepper, but the mean length of a complete shifting cultivation cycle there was 12 years, while in Antonio Raimondi it was only five years. We also found that mean duration of fallow in Pimental is twice as long (six years, as compared to three years in Antonio Raimondi). Although Mertz et al. [1], in their case study from Kalimantan, wrote that fallow length is a weak predictor of crop yield (and thus sustainability of the system), we found a positive relationship between the length of the fallow and the length of the subsequent cropping period. When fallow period is longer, subsequent cropping can also be longer and more diversified. It seems that larger area taken by pastures and degraded land in Antonio Raimondi could be a consequence of a shorter fallowing period and the subsequent rapid weed proliferation and soil degradation.

According to Boserup [19], shifting cultivation systems usually evolve toward "annual cropping" and "multiple cropping" systems through a progressive reduction in fallow length and fire intensity. Woody vegetation is eliminated from the fields and interplanting of trees and crops only occurs in the later stages of intensification, when there is no more space to establish a pure plantation. The small farmers around Pucallpa now find themselves in this transition period. The question arises whether the system of annual cropping can be sustained in such an environment of low soil fertility and noxious weeds. It seems that fallowing remains a very important part of the local shifting cultivation cycle, but a transition to more intensified land use systems could be achieved through tree-based systems such as perennial fruit or timber tree plantations, or an agroforestry mixture. These systems could substitute for the biological role of natural fallow (soil fertility maintenance and weed control) and bring the farmers the necessary return on their investment (fruit, timber and non-timber products). Development agencies should not provide farmers with complete, fixed technological packages, but should design technologies in a less specific manner, thus allowing for flexibility in their appropriation by farmers [20].

\section{CONCLUSIONS}

Based on our results, we can conclude that, although land use patterns after initial slash-and-burn were similar in both study areas, considerable local diversity as well as variations in principal crop composition and fallow length occur in local shifting cultivation system. This is 
due to the different backgrounds and histories of the settlers. The rate of land degradation and forest conversion to other uses is much higher in the more recently-established settlement as a consequence of population pressure and population structure, consisting predominantly of migrant peasants. Due to this fact and the shorter fallow period (lack of perennial cropping tradition), the process of forest destruction is much more pronounced in Antonio Raimondi than in the older study site. Small-scale farmers in both study areas are now facing a problem with the transition from shifting cultivation to sedentary farming.

The settlement where cultivation of market-oriented perennials was introduced by its founders seems to be permanent and more sustainable. The rate of forest destruction and land degradation is relatively slower in settlements where perennials are planted than in settlements where annual crops prevail. Fallow length is primarily influenced by the type of principal crop composition and access to available land. Farmers focused mainly on annual cropping employ a significantly shorter fallow period and thus higher rate of forest degradation occurs. As annual cropping seems to be unsustainable, farmers should either continue using a longer natural fallow period to sustain longer cropping cycles, or shift to perennial tree-based land use systems that require a higher initial investment, but brings larger benefits in the future. Moreover, according to our study, farmers in the study area use a considerable variety of useful tree species; this could be an advantage for wider use of them. We have to agree with the hypothesis presented by Fujisaka and White [10], that diminishing pioneer conditions favour mixed systems that include perennial crops with high-value products (e.g. coffee, cocoa, fruit, timber). However, there is the risk of failure of such an establishment as promoted by development projects, when market projections are incomplete.

\section{ACKNOWLEDGEMENTS}

This research was conducted with financial support from the Foundation Nadání Josefa, Marie a Zdeňky Hlavkových, Czech Republic, Youth Activity Fund Of Explorers Club, USA and the Czech Ministry of Agriculture within the Czech Republic Development Cooperation program, project number 23/MZE/B/07-10.

\section{REFERENCES}

[1] Mertz, O., Wadley, R.L., Nielsen, U., Bruun, B.T., Colfer, C.J.P., de Neergaard, A., Jepsen, M.R., Martinussen, T., Zhao, Q., Noweg, G.T. and Magid, J. (2008) A fresh look at shifting cultivation: Fallow length and uncertain indicator of productivity. Agricultural Systems, 96, 75-84. doi:10.1016/j.agsy.2007.06.002

[2] Mertz, O. (2009) Trends in shifting cultivation and the
REDD mechanism. Current Opinion in Environmental Sustainability, 1, 156-160.

doi:10.1016/j.cosust.2009.10.002

[3] FAO. (2005) State of the World's Forest. Food and Agriculture Organization of the United Nations, Rome, Italy.

[4] Warner, K. (1991) Shifting cultivators-Local technical knowledge and natural resource management in the humid tropics. Food and Agriculture Organization's Community Forestry Note, 8, Rome, Italy.

[5] Russell, W.M.S. (1988) Population, swidden farming and the tropical environment. Population and Environment, 10, 77-94. doi:10.1007/BF01359134

[6] Kleinman, P.J.A., Pimentel, D. and Bryant, R.B. (1996) Assessing the ecological sustainability of slash-and-burn agriculture through soil fertility indicators, Agronomic Journal, 88, 122-127. doi:10.2134/agronj1996.00021962008800020002x

[7] Sanchez, P.A., Palm, C.A., Vosti, S.A., Tomich, T. and Kasyoki, J. (2005) Alternatives to slash and burn. Challenges and approaches of an international consor- tium. In: Palm, C.A., Vosti, S.A., Sanchez, P.A. and Ericksen, P.J. Eds., Slash-and-Burn Agriculture. The Search for Alternatives, Columbia University Press, New York, 3-37.

[8] Nair, P.K.R. (1993) An introduction to agroforestry. Kluwer Academic Publishers, Dordrecht, The Netherlands.

[9] Serrao, E.A.S., Nepstad, D. and Walker, R. (1996) Upland agricultural and forestry development in the Amazon: sustainability, criticality and resilience. Ecological Economics, 18, 3-13. doi:10.1016/0921-8009(95)00092-5

[10] Fujisaka, S. and White, D. (1998) Pasture or permanent crops after slash-and-burn cultivation? Land use choice in three Amazon colonies. Agroforestry Systems, 42, 45-59. doi:10.1023/A:1006195810077

[11] Olivera, P.J.C., Asner, G.P., Knapp, D.E., Almeyda, A., Galván-Gildemeister, R., Keene, S., Raybin, R.F. and Smith, R.C. (2007) Land use allocation protects the peruvian amazon. Science, 317, 1233-1237. doi:10.1126/science.1146324

[12] Holm, L.G., Plucknett, D.L., Pancho, J.V. and Herberger, J.P. (1997) The World's Worst Weeds: Distribution and Biology. University Press of Hawaii, Hawaii, USA.

[13] Garrity, D.P., Soekardi, M., De La Cruz, R., Pathak, P.S., Gunasena, H.P.M., Van So, N., Huijin, G. and Majid, N.M. (1997) The Imperata grasslands of tropical Asia: area, distribution, and typology. Agroforestry Systems, 36, 3-29. doi:10.1007/BF00142865

[14] Hartemink, A.E. (2001) Biomass and nutrient accumulation of Piper aduncum and Imperata cylindrica fallows in the humid lowlands of Papua New Guinea. Forest Ecology and Management, 144, 19-32. doi:10.1016/S0378-1127(00)00655-1

[15] Albers, H.J. and Goldbach, M.J. (2000) Irreversible ecosystem change, species competition, and shifting cultivation. Resource and Energy Economics, 22, 261280. doi:10.1016/S0928-7655(00)00034-8

[16] Coomes, O.T. and Burt, G.J. (1997) Indigenous marketoriented agroforestry: Dissecting local diversity in western Amazonia. Agroforestry Systems, 37, 27-44. 
doi:10.1023/A:1005834816188

[17] Fujisaka, S., Escobar, G. and Veneklaas, E. (1999) Plant community diversity relative to human land uses in an Amazon forest colony. Biodiversity Conservation, 7, 41-57. doi:10.1023/A:1008855612209

[18] de Jong, W. (1995) Diversity, variation and change in Ribereno agriculture and agroforestry. Doctoral Thesis, Wageningen University for Life Sciences, The Netherlands.
[19] Boserup, E. (1965) The Conditions of Agricultural Growth: The Economics of Agrarian Change Under Population Pressure. Earthscan Publication Ltd., London.

[20] Pollini, J. (2009) Agroforestry and the search for alternatives to slash-and-burn cultivation: From technological optimism to a political economy of deforestation. Agriculture, Ecosystems and Environment, 133, 48-60. doi:10.1016/j.agee.2009.05.002 